\title{
Why Thucydides' Trap Misinforms Sino-American Relations
}

\author{
Steve Chan \\ University of Colorado (Boulder), Colorado, USA \\ \steve.chan@colorado.edu
}

\begin{abstract}
Thucydides' Trap" has become a familiar term in scholarly and even popular discourse on SinoAmerican relations. It points to the ancient rivalry between Athens and Sparta as an analogy for contemporary relations between China and the United States. This analogy warns about the increased danger of war when a rising power catches up to an established power. This essay raises concerns about (mis)application of historical analogy, selection bias, measurement problems, underspecified causal mechanisms, and so on that undermine the validity of the diagnosis and prognosis inspired by this analogy and other similar works. My objection to this genre of scholarship does not exclude the possibility that China and the U.S. can have a serious conflict. I only argue that this conflict can stem from sources other than any power shift between them or in addition to such a shift. By overlooking other plausible factors that can contribute to war occurrence, a monocausal explanation such as Thucydides' Trap obscures rather than clarifies this phenomenon. Because it lends itself to a sensationalist, even alarmist, characterization of a rising China and a declining U.S. (when the latter in fact continues to enjoy important enduring advantages over the former), this perspective can abet views and feelings that engender self-fulfilling prophecy. Finally, as with other structural theories of interstate relations, Thucydides' Trap and other similar formulations like power-transition theory tend to give short shrift to human agency, including people's ability to learn from the past and therefore to escape from the mistakes of their predecessors.

Key words: Thucydides' Trap, power transition, Sino-American relations, historical analogies, structure and agency, self-fulfilling prophecy
\end{abstract}

For citation: Chan, S. (2021). Why Thucydides' Trap Misinforms Sino-American Relations. Vestnik RUDN. International Relations, 21(2), 232-242. https://doi.org/10.22363/2313-0660-2021-21-2-232-242

\section{Почему «ловушка Фукидида» вводит в заблуждение относительно американо-китайских отношений}

\section{С. Чан}

Университет штата Колорадо, Боулдер, Колорадо, США

$\triangle$ steve.chan@colorado.edu

Аннотация. «Ловушка Фукидида» стала привычным термином в академическом и даже научнопопулярном дискурсе о китайско-американских отношениях. Он отсылает нас к античному соперничеству между Афинами и Спартой как аналогии для современных отношений между Китаем и США. Эта аналогия предупреждает о возрастающей опасности войны, когда восходящая держава достигает уровня развития, схожего с уровнем существующего гегемона. Автор выражает озабоченность по поводу «неправильного» применения данной исторической аналогии - предвзятости, связанной со структурой выборки, проблемами

(C) Chan S., 2021

This work is licensed under a Creative Commons Attribution 4.0 International License.

https://creativecommons.org/licenses/by/4.0/ 
ее оценки, не до конца определенными причинно-следственными механизмами и т. д., которое подрывает обоснованность прогноза, основанного на этой аналогии и других подобных работах. При этом не исключается возможность серьезного конфликта между Китаем и США, который, однако, может проистекать из иных причин, а не из прямого или косвенного изменения их силовых показателей. Не обращая внимания на другие вероятные факторы, которые могут способствовать возникновению открытого конфликта, причинноследственное объяснение, такое как «ловушка Фукидида», скорее вводит в заблуждение, не проясняя сложившуюся ситуацию в американо-китайских отношениях. Поскольку в ее рамках дается сенсационная, а порой и паникерская характеристика возвышения Китая и упадка США (когда на самом деле США до сих пор обладают рядом важных устойчивых преимуществ по сравнению с КНР), подобный подход может способствовать развитию взглядов, порождающих самоисполняющееся пророчество. Наконец, как и в случае с другими структурными теориями межгосударственных отношений, «ловушка Фукидида» и другие аналогичные теории, такие как теория транзита власти, как правило, недооценивают человеческую свободу действий, в том числе способность людей извлекать уроки из прошлого и, следовательно, избегать ошибок своих предшественников.

Ключевые слова: «ловушка Фукидида», транзит власти, китайско-американские отношения, исторические аналогии, структура и агентность, самоисполняющееся пророчество

Для цитирования: Chan S. Why Thucydides' Trap Misinforms Sino-American Relations // Вестник Российского университета дружбы народов. Серия: Международные отношения. 2021. Т. 21. № 2. С. 232-242. DOI: 10.22363/2313-0660-2021-21-2-232-242

\section{Introduction}

“Thucydides' Trap" has become a popular term in narratives about relations between China and the U.S. This term owes its popularity to Allison's [2017] influential work, and refers to Thucydides' explanation of the origin of the Peloponnesian War. This ancient Greek historian is remembered by his pithy maxim, usually translated to say that the rise of Athens and the fear that this development had inspired in Sparta was the basic, even inevitable, cause of this devastating war some 2,500 years ago ${ }^{1}$. Allison has highlighted this maxim and generalized it to say that when a rising state catches up to an established state, the danger of war between them becomes elevated. He reports that of the sixteen historical episodes he studied when a "rising state" reaches power parity or overtakes a "ruling state", twelve ended in war. The clear implication is that as China becomes more powerful, the danger of war between it and the U.S. rises. His writing was predated by others who have also warned about the danger of war breaking out when there is a power transition

\footnotetext{
${ }^{1}$ There are different translations of Thucydides' words. The version offered by Kagan [1969: 2-3] states: “...the truest cause, but the least spoken of [the Peloponnesian War], was the growth of Athenian power, which presented an object of fear to the Spartans and forced them to go to war".
}

(e.g., [Gilpin 1981; Organski 1958; Organski, Kugler 1980]). Power-transition theory has spawned a large body of empirical, usually quantitative, research [Tammen, Kugler, Lemke 2017].

I have written extensively elsewhere [Chan 2004, 2005, 2007, 2014, 2017, 2019, 2020a, 2020b; Chan, Hu, He 2019; Chan, Feng, He, Hu 2021] about the flaws in Allison and powertransition scholars' analyses ${ }^{2}$. In the following discussion, I highlight and explain my reservations about and objections to their explanation of interstate wars in general and contemporary Sino-American relations specifically. Much of this discussion raises new issues and concerns in addition to those that I have already presented previously. Those interested in this topic can consult other helpful reviews and critiques of this literature (e.g., [DiCicco, Levy 1999; Kirshner 2019; Lebow, Valentino 2009; Vasquez 1996; Welch 2015]).

\footnotetext{
${ }^{2}$ See: Response by Steve Chan. H-Diplo/ISSF Roundtablen12-2 // H-Net: Humanities \& Social Sciences Online. November 9, 2020. URL: https://networks. h-net.org/node/28443/discussions/6721850/h-diploissfroundtable-12-2-thucydides $\% \mathrm{E} 2 \% 80 \% 99$ s-trap-historical (accessed: 10.01.2021); Chan S. The World in Which China Will Have to Operate in the Foreseeable Future: The Persistence of U.S. Structural Power. Paper presented at Workshop on China's Influence, University of Hong Kong, 2020 .
} 


\section{Presentist Fallacy}

By invoking Thucydides, Allison gives his own argument "an appearance of being timeless"3. In this practice, "we tend to read IR [international relations] concepts back into classical texts and periods not because they are brilliantly trans-historical, but because presenting them as such is a legitimation strategy for our presentist arguments". We introduce our own contemporary understanding and impose it on our interpretation of classical texts and figures. This does not mean that studying trans-historical dynamics is unimportant, "but rather such dynamics are difficult to locate and even harder to theorise without bringing in biases and connotations of the present". Thus, Zarakol warns us about the tendency for confirmation bias, bringing in the past to validate our contemporary views 4 .

Although Thucydides speaks of systemic pressures stemming from shifting power balance that inclined Athens and Sparta to go to war, his rich and nuanced narrative also points to the important role played by domestic partisanship, differences in regime character, interactions among allies and, not the least, human emotions and calculations in influencing decision making [Kirshner 2019; Welch 2015]. In Waltz's [1954] well-known terminology, Thucydides not only emphasized the "third image" of international relations (that is, systemic factors at the interstate level of analysis) but also "second" and "first images" focusing respectively on the nature of polities and individuals. Allison simply latches on Thucydides' comment on the changing power relationship between Athens and Sparta and names his own argument after Thucydides.

\section{Misleading Analogy}

Was Sparta alarmed by the rise of Athenian power or rather Athens' policy of imperial expansion that had increased its power? Arguing

\footnotetext{
${ }^{3}$ Review by Ayşe Zarakol. H-Diplo/ISSF Roundtablen12-2 // H-Net: Humanities \& Social Sciences Online. November 9, 2020. URL: https://networks. h-net.org/node/28443/discussions/6721850/h-diploissfroundtable-12-2-thucydides $\% \mathrm{E} 2 \% 80 \% 99 \mathrm{~s}$-trap-historical (accessed: 10.01.2021).

${ }^{4}$ Ibid.
}

in favor of the latter interpretation, Lee [2019] questions whether Thucydides himself would have agreed with Thucydides' Trap. This is not a trivial distinction because it is one thing to speak of Athens' rising power due to its foreign expansion, and another to attribute this rising power to its domestic growth. It is obviously pertinent to today's Sino-American relations. Has China's rising power been due to its imperial pursuits or domestically based growth? Allison does not address this question about the sources of changing national power. Most contemporary power-transition theorists (e.g., [Organski, Kugler 1980; Tammen, Kugler, Lemke, Stam, Abdollahian et al. 2000]) insist that national power is determined primarily by economic growth reflecting domestic conditions and policies. Gilpin [1981] points especially to differential rates of economic growth to be the basic driver altering interstate distribution of power.

These remarks naturally lead to the question whether China has been pursuing an agenda of imperial expansion to provide the basis for its growing power - as in the case of Athens which had forced other Greek polities to pay tributes and thus to contribute to its war chest. Comparing China with the U.S., which one fits better the profile of building an empire with formal and informal allies, military bases, and multinational corporations all over the world? Which one has arguably based its power on its domestic economic growth (albeit with an emphasis on exports), and which one has pursued an aggressive foreign policy featuring war, conquest, and regime change abroad (Afghanistan, Iraq, Libya, Syria, Venezuela)?

Historical analogies can illuminate but they can also distort and misinform [Khong 1992]. How relevant is an analogy taken from the premodern Greek world to contemporary international relations? Many things have happened in the intervening years, such as the advent of modern state, nationalism, and nuclear weapons. Would any of these developments affect the validity of the proposition attributed to Thucydides? For instance, we may want to ask what interest would be important enough for the U.S. and China to run the risk of nuclear 
destruction. What would they be fighting over? Allison is silent on this question, although power-transition theorists aver that leading states fight over which one of them should decide "the international order". They do not, however, explain what they mean by this concept [Chan, Feng, He, Hu 2021]. Thucydides tells us that the Greeks were motivated to go to war because of fear, honor, and interest ("advantage"). What would be the motivations for contemporary China and the U.S. to get into a fight? What stakes would be sufficiently important for them to risk mutual destruction?

We must consider the extent to which ancient Athens (the ostensible rising state) and Sparta (the ostensible established state) provide cogent parallels to today's China and the U.S. Athens was a "democratic" polity by the standards of its time, and it drew its power from its overseas commerce and naval prowess. In contrast, Sparta was an oligarchy and featured an agrarian economy. Its infantry of hoplites was the source of its military power. These characteristics obviously do not correspond to the contemporary profiles of China and the U.S. respectively. Unlike Athens, China (the rising state) is a land power, and it has an authoritarian government. In contrast to Sparta, the U.S. is a maritime power with global reach, and it is a democracy. Extensive research shows that a country's regime type, its commercial orientation, the source of its military strength, and its regional or global position have important influences on its warproneness (e.g., [Russett, Oneal 2001; Levy, Thompson 2010]). None of these factors was taken into systematic account in Allison's presentation of Thucydides' Trap.

\section{Monocausal Explanation}

The last comment in turn points to another weakness in Allison's formulation of Thucydides' Trap. It presents a monocausal explanation, claiming that a power shift between two countries raises the danger of war between them. Research on international relations has advanced considerably beyond such bivariate proposition. To confirm that $\mathrm{A}$ really has a causal impact on B as hypothesized, we would need to control for the effects of C, D, and $\mathrm{E}$ (such as those variables mentioned at the end of last section). In other words, we need to rule out spurious interpretations. At the very least, we would want to know whether A's influence on B's occurrence is greater than that of C, D, and E. Allison makes no attempt to show that power transition is really the primary reason inclining states to go to war. Although power-transition theory suggests whether a rising power has a "revisionist" agenda is another determinant for war occurrence, its proponents rarely incorporate this variable in their research ${ }^{5}$.

We learn from Thucydides that multiple and not necessarily mutually exclusive paths led to the outbreak of the Peloponnesian War [Chan 2019; Welch 2015]. These paths include "push factors" such as domestic hawks advocating a hardline policy, and "pull factors" such as alliance commitments that entrap a polity in dubious foreign intervention. Moreover, there are human frailties such as hubris and arrogance. Thucydides' masterful narrative provides ample evidence showing that a combination of forces conspired to produce this conflict, whose occurrence cannot be reduced to a single factor such as power transition.

\section{Context and Contingency}

Following the last remark, we would do well to consider what other structural factors may abet and compound the influence of power transition on the probability of war breaking out and, conversely, which factors may dampen this influence. In other words, in which context is the occurrence of a power transition especially dangerous for international peace and stability? For instance, one may argue that when power transition occurs in the context of an ongoing armament race, longstanding rivalry, and bipolarized alliances between states that are proximate neighbors, it is especially likely to contribute to a combustible brew leading to war

\footnotetext{
${ }^{5}$ Response by Steve Chan. H-Diplo/ISSF Roundtablen12-2 // H-Net: Humanities \& Social Sciences Online. November 9, 2020. URL: https://networks. h-net.org/node/28443/discussions/6721850/h-diploissfroundtable- 12 -2-thucydides $\% \mathrm{E} 2 \% 80 \% 99 \mathrm{~s}$-trap-historical (accessed: 10.01.2021). See also: [Chan 2020b; Chan, Hu, He 2019; Chan, Feng, He, Hu 2021].
} 
(e.g., [Thompson 2003]). In this circumstance, we have potentially a multiplier interaction among the variables just mentioned so that each of them abets and compounds the effects of the others and together they produce a conflict spiral that threatens to escape officials' control. In such a situation, an incident such as the assassination of Archduke Ferdinand in Sarajevo could be just a spark for a large conflagration waiting to happen. Conversely, when power transition happens in the absence of one or more of the other variables just mentioned, it is much less likely to lead to war.

Thus, there have been many power transitions without a war happening in their wake (such as those I mention later). The Peloponnesian War originated from a dispute between secondary polities (Corinth and Corcyra) that were Athens or Sparta's allies. Serbia (Russia's protégé in 1914) and Taiwan (an American client today) provide parallels suggesting that great powers can be dragged into a war because of their alliance entanglements rather than just real or imagined power transition.

Although Allison suggests that power transition increases the danger of war, he does not believe war to be inevitable. Thus, he does not have a deterministic view that power transition causes war. As Kirshner [2019: 3] emphasizes, Thucydides assigns a "central role [to] uncertainty and contingency in explaining outcomes. [He] goes to great lengths to show that things need not to have occurred as they did". There were heated debates in the Athenian and Spartan assemblies between "peace" and "war" parties and even vacillations and reversals of decisions among those who favored a moderate or hardline policy in the deliberations leading to war. At various critical junctures, the decisions to go to war and the outcomes of fighting were a "close call", meaning that things could have easily turned out differently.

\section{Missing Link}

Why should a power transition between two countries incline them to go to war? We do not know whether there was in fact a power shift between Athens and Sparta. We can only infer from the statements made by their leaders and associates. Saying so means that ultimately it is people acting on their perceptions that decide war and peace. As they are currently formulated, neither Allison's Thucydides' Trap nor powertransition theory provide us with a causal mechanism that transmits the effects of a development at the level of interstate relations (namely, a power shift between two states) to the individual or group level of policy making. Why and how should we expect the former to influence the latter? Although Thucydides mentioned Spartans' fear of Athens' rise, Allison does not explain how China's recent power gains should affect its officials' perceptions and thinking and those of their U.S. counterparts.

Domestic partisan rivalry, leaders' political ambitions, and their personal characters played a role in the contested processes of decision making in Athens and Sparta's assemblies. Hubris, greed, and fear were among those emotions that "pushed" them to war. In addition, the Athenians and Spartans felt their honor and interests were engaged in the defense of their respective allies. Their alliance commitments therefore also "pulled" them into conflict. Politicians can deploy the rhetoric of power transition to frame political discourse and promote their own personal agenda. Although they can rarely agree on anything else, getting tough on China has become a consensus for Democrats and Republicans in the U.S. This posture has also been a key part of Donald Trump's re-election campaign. Allison's analysis overlooks the dynamics of two-level games connecting international and domestic politics [Putnam 1988], whereas Thucydides' account went into great lengths about such interactions.

\section{Social and Political Construction}

Few people will disagree with the proposition that China has significantly improved its international position. We would, however, be remiss to overlook the social and political construction behind much of power-transition discourse. By social and political construction, I mean the promotion, propagation, and entrenchment of certain ideas as in Gramsci's [1971] discussion of hegemony of ideas, and the influence of U.S. soft power on international 
relations discourse [Nye 2004]. My larger point is, to paraphrase Wendt [1992], power transitions are what states make of it.

Power-transition theory disregards the one and only instance of the baton of international leadership being passed from Britain to the U.S. It instead chooses to focus on the two world wars as Germany's efforts to challenge Britain's primacy. Had this theory considered the AngloAmerican transition, its prediction would have been falsified because war did not happen in its wake. Moreover, Germany never overtook or even came close to the U.S. in its economic or military power. Only by declaring that the U.S. was not a contender in the central system of international relations as late as 1938, powertransition theory was able to exclude this country in its explanation of the two world wars, thus (mis)representing both conflicts as a contest between Germany and Britain.

Thus ironically, power-transition theory dismisses the only historical case of power transition at the pinnacle of interstate system since 1815, the one between the U.S. and Britain that turned out to be peaceful. But it sounds the alarm about a possible war when it comes to a possible but still highly uncertain power transition in the future, namely the one between China and the U.S. It argues that the U.S. should not be considered a factor in the explanation of the two world wars on the grounds that it was still not a major player in interstate relations in 1938 even though its role was decisive in Germany's defeat in 1918. In contrast, it points to the threat posed by China to the U.S. as the world's only superpower, even though China today is still just a regional power with very limited military reach beyond its borders. Beijing is hardly capable of challenging U.S. primacy in the Western Hemisphere, Western Europe, and the Middle East.

Power-transition theory also claims that wars are initiated by a "revisionist" rising power. As I have explained elsewhere [Chan 2004, 2007, 2020b; Chan, Feng, He, Hu 2021], some states designated as "revisionist" such as Wilhelmine Germany and Imperial Japan did not behave differently from the precedents set by other expanding powers such as Britain, France, and the U.S. They were simply following the footsteps of these predecessors. Thus, the "revisionist" classification tends to be a post hoc label deployed to indicate that a country had fought against "us". There is scant attention paid to the possibility that a dominant power can wage a preventive war against a weaker but rapidly rising power, such as when Germany launched its attack against Russia / the USSR in 1914 and again in 1941 [Copeland 2000]. Powertransition theory was able to (mis)represent the two world wars as a German challenge to Britain (that is, a latecomer initiating a war against an established power) only by eliding over the Russo-German dyad (a stronger Germany seeking to eliminate a potential future competitor in rising Russia / the USSR by launching a preventive war against it).

Significantly, by their very design Thucydides' Trap and power-transition theory do not and cannot answer the question whether when an already dominant power becomes even more powerful, it is more inclined to wage war such as shown by increased U.S. aggression (e.g., Iraq, Afghanistan, Libya, Syria) after attaining its unipolar status after the USSR's dissolution. There is a long and venerable theoretical tradition arguing that a balance of power is conductive to peace and stability. Thucydides' Trap and power-transition theory of course argue the very opposite, contending or at least implying that hegemony by a dominant power promotes peace and stability whereas a (greater) balance of power (such as when a power transition occurs) threatens war. Their normative implication should be evident.

\section{Questionable Metric and Accounting Unit}

Allison was not explicit in how he measures power transition. How do we know whether A has caught up to B or even overtaken B? This question is fundamental to anyone who is interested in studying interstate power shifts.

Both Allison and other power-transition scholars tend to favor stocks of tangible resources, such as a country's economic size and its export volume. Measures of physical bulk exaggerate China's power whether that is a country's population, territory, iron / steel 
production, energy consumption, or military personnel [Chan 2005, 2014]. Although these measures may be relevant to indicating national power before World War II, they are quite misleading for today's world where this power is no longer accurately reflected in the size of a country's "smokestack" industry or its infantry. The Composite Index of National Capability based on such measures [Singer, Bremer, Stuckey 1972] reported that the USSR had overtaken the U.S. just before the former country disintegrated. National power today is more accurately reflected in a country's capacity to undertake technological innovation at the cutting edge of science and to pioneer leading industries such as information technology. Although the size of an economy or population is not irrelevant to national power, productivity as indicated by per capita income can be more illuminating. Seen in this light, average U.S. income in 2019 was 6.38 times greater than average Chinese income in nominal terms and 3.32 times greater if adjusted for purchasing power parity ${ }^{6}$. Moreover, as Starrs [2013] points out, what matters is not so much in which country the physical assembly of a product takes place; the more important consideration is which country's companies own and control the most valuable parts of the cross-border production chain (such as a product's branding, design, and marketing).

In today's globalized economy, the U.S. enjoys a tremendous advantage in its network centrality ${ }^{7}$. The primacy of the U.S. dollar, the dominance of U.S. multinational corporations,

\footnotetext{
${ }^{6}$ Comparing United States and China by Economy // Statistics Times. August 02, 2019. URL: http://statisticstimes.com/economy/united-states-vs-chinaeconomy.php (accessed: 10.01.2021). In 2019, the U.S. spent more on its military than the next eleven countries combined. Its defense spending was 2.8 times higher than China's. For more information see: Tian N., Fleurant A., Kuimova A., Wezeman P.D., Wezeman S.T. Trends in World Military Expenditure, 2019 // SIPRI Fact Sheet. April 2020. URL: https://www.sipri.org/sites/default/ files/2020-04/fs 202004 milex 0 0.pdf (accessed: 10.01.2021).

${ }^{7}$ Chan S. The World in Which China Will Have to Operate in the Foreseeable Future: The Persistence of U.S. Structural Power. Paper presented at Workshop on China's Influence, University of Hong Kong, 2020.
}

and the technological control exercised by U.S. internet companies give this country an incomparable advantage. Moreover, the U.S. military commands the global commons in sea, air, and space [Posen 2003], its nuclear capability threatens China and Russia's ability to retaliate [Lieber, Press 2006], and it deploys its military assets in forward positions right up to Chinese and Russian borders in a vast alliance network. Its military technology is also decades ahead of China [Brooks, Wohlforth 2016; Gilli, Gilli 2019].

International relations cannot be captured in bilateral terms such as by matching China and the U.S. After all, large conflicts such as the two world wars are fought by alliances. It was the superior strength of opposing coalition that defeated Napoleon, Kaiser Wilhelm, and Hitler. There is no doubt which side Australia, Britain, and Canada will support in a possible SinoAmerican confrontation. It is difficult to imagine which countries China can count on to fight on its side.

As already noted, Allison [2017] takes changes in countries' power positions as exogenously given ${ }^{8}$. He does not explore the reasons behind these changes. In contrast, powertransition theorists emphasize that these changes are driven primarily by domestic factors [Gilpin 1981; Organski, Kugler 1980]. Although they stress the importance of a state's ability to effectively extract, mobilize, and deploy its resources, that is, its policy capacity [Arbetman, Kugler 1997; Kugler, Tammen 2012], they have not actually incorporated this consideration in their analysis of power transitions ${ }^{9}$. By just

${ }^{8}$ Allison G. The Thucydides Trap: Are the U.S. and China Headed or War? // The Atlantic. September 24, 2015. URL: www.theatlantic.com/international/archive/ 2015/09/united-states-china-war-thucydides-trap/406756/ (accessed: 10.01.2021). See also: [Beckley 2012; Farrell, Newman 2019; Starrs 2013].

${ }^{9}$ Fukuyama makes this point regarding the poorer U.S. performance to contain the COVID-19 pandemic relative to other states, emphasizing state capacity, social trust, and leadership as key determinants of this performance. For more information see: Fukuyama F. The Pandemic and the Political Order: It Takes a State // Foreign Affairs. July/August 2020. URL: https:/www.foreignaffairs.com/ articles/world/2020-06-09/pandemic-and-political-order (accessed: 10.01.2021). 
counting stocks of tangible (material) resources without paying attention to policy capacity, one would have missed badly the outcomes of the Vietnam, Korean, and other wars.

\section{Dubious Designation and Selection}

Allison did not explain his criteria for designating "rising states" and "ruling states". He considers Britain and France to be still "ruling states" as late as the 1990s. His cases are a mixture encompassing states that were not necessarily the most powerful in the world. Power-transition theory is more explicit, stating that it is concerned about systemic wars fought by the world's two most powerful countries over who should decide "international order". In practice, however, power-transition theorists have included wars fought by those that were clearly not the two leading states at the time or about the nature of international order. Organski and Kugler's [1980] study included the FrancoPrussian and Russo-Japanese Wars in addition to the two world wars. Allison omitted wars waged by Western powers against China's declining Qing Dynasty (including the infamous Opium Wars). The Spanish-American War fought between an obviously rising power and a declining one was also missing. Thus, the criteria for selecting (or omitting) cases, both those states involved in ostensible power transitions and the wars they fought, are arbitrary.

Organski and Kugler's [1980] analysis is also problematic because it selects on the dependent variable. It picks the four wars just mentioned and asks whether there was any power transition for selected pairs of countries around their occurrence. It does not consider how often power transitions have happened historically without war. Thus, it does not ask "why the dog did not bark" - the non-occurrence of the expected. Allison's case inventory includes four peaceful power transitions. Still, he under-reports this phenomenon such as when at least economically, Germany overtook Russia, Japan overtook Britain, France, and Germany, and China overtook all these countries in recent decades. By omitting these cases, he inflates the association between power transition and war. Surely, wars have also happened without a power transition such as when China and the U.S. fought in Korea.

\section{Policy Implications}

Pericles warned his fellow Athenians "not to extend your empire at the same time as you are fighting the war and not to add self-imposed dangers, for I am more afraid of our own mistakes than the strategy of our opponents" [Kagan 1969: 192]. These words were prescient in pointing to imperial overstretch and domestic dysfunctions in weakening a country's international position (e.g., [Kennedy 1987; Schweller 2006])

Kirshner [2019: 7-8] reminds us that the greatest lesson is 'Thucydides' exposition of how, as Pericles had feared, it was not the power and designs of adversaries that led to Athenian defeat and ruin but rather hubris in the form of reckless overambition. Athens fell not because it was overtaken by rivals but rather because it became intoxicated with the idea of its own greatness and could not recognize the limits of its own power". The pertinence of this observation to contemporary Sino-American relations should be obvious. Overconfidence, self-righteousness, arrogance, and ethnocentrism, in addition to paranoia, prejudice, and mistrust, rather than power transition per se, are the more important ingredients that abet interstate conflict.

Although China has "risen", it is still significantly behind the U.S. Talks of a SinoAmerican power transition are greatly exaggerated and premature. They suggest social and political construction that arouses elite and popular emotions such as those just mentioned. This discourse accuses China of seeking to evict the U.S. from its home region (East Asia) exactly what the U.S. itself had done over a century ago by declaring the Monroe Doctrine to exclude European influence from the Western Hemisphere. It fosters the danger of self-fulfilling prophecy. Moreover, it does not emphasize enough human agency. History repeats itself by "trapping" leaders in a collision course only if they are incapable of learning from it.

After all, many power transitions have ended peacefully. Chinese leaders can be expected to 
draw lessons from Germany and Japan's disastrous bid for regional hegemony, the USSR's equally calamitous decision to compete with the U.S. in armament and for allies, and the peaceful transition of world leadership from Britain to the U.S. It would also be remiss for U.S. leaders to overlook the smart "appeasement" policies that Britain had adopted before World War I, enabling it to recruit important allies such as the U.S., France, and Russia and thereby to defeat Germany [Treisman 2004].

One of the key lessons from this conflict and World War II is that although Britain might be in some respects weaker than Germany, the coalition fighting on its side was stronger and enabled it to prevail in both wars. The USSR had lost the Cold War in part also because the U.S. had more powerful allies that further extended its own already formidable advantages. If these conclusions make sense, it would be foolhardy for Beijing to follow Moscow's example during the Cold War to engage in "hard balancing" against Washington or, to use Rosecrance's [1986] terminology, to pursue the agenda of a "strategic state" such as by pursuing ideological proselytization, military competition, and the recruitment of foreign clients. Chinese leaders can also learn from Mikhail Gorbachev that unilateral accommodation tends to encourage increased U.S. pressure for more concessions [Shifrinson 2018].

As for the U.S., it should heed Pericles' warning about hubris and overweening ambition, and the dangers of imperial overstretch and dysfunctional domestic politics. It would also be imprudent for Washington to undertake a myopic and self-defeating policy of "going alone", undermining the liberal international order [Ikenberry 2001, 2008, 2011] and breaking up a winning coalition that are the sources of its greatest strengths. Learning from history can help China and the U.S. to avoid the trap that Thucydides had supposedly warned us about.

Received / Поступила в редакцию: 21.01.2021

Accepted / Принята к публикации: 02.04.2021

\section{References / Библиографический список}

Allison, G. (2017). Destined for war: Can America and China escape Thucydides's Trap? Boston: Houghton Mifflin Harcourt.

Arbetman, M., \& Kugler, J. (Eds.). (1997). Political capacity and economic behavior. Boulder, CO: Westview.

Beckley, M. (2012). China century? Why America's edge will endure. International Security, 36(3), 41-78. https://dx.doi.org/10.1162/ISEC_a_00066

Brooks, S.G., \& Wohlforth, W.C. (2016). The rise and fall of the Great Powers in the twenty-first century: China's rise and the fate of America's global position. International Security, 40(3), 7-53. https://dx.doi.org/ 10.1162/ISEC_a_00225

Chan, S. (2004). Exploring some puzzles in power-transition theory: Some implications for Sino-American relations. Security Studies, 13(3), 103-141. https://dx.doi.org/10.1080/09636410490914077

Chan, S. (2005). Is there a power transition between the U.S. and China? The different faces of power. Asian Survey, 45(5), 687-701. https://dx.doi.org/10.1525/as.2005.45.5.687

Chan, S. (2007). China, the U.S., and the power-transition theory: A critique. New York: Routledge.

Chan, S. (2014). So, what about power shift? Caveat emptor. Asian Perspective, 38(3), 363-386. https://dx.doi.org/10.1353/apr.2014.0015

Chan, S. (2017). The power-transition discourse and China's rise. In W.R. Thompson (Eds.), The Oxford encyclopedia of empirical international relations theory. New York: Oxford University Press. https://dx.doi.org/10.1093/acrefore/9780190228637.013.561

Chan, S. (2019). More than one trap: Problematic interpretations and overlooked lessons from Thucydides. Journal of Chinese Political Science, 24(1), 11-24. https://dx.doi.org/10.1007/s11366-018-9583-2

Chan, S. (2020a). China and Thucydides's Trap. In K. He, H.Y. Feng (Eds.), China's challenges and international order transition: Beyond the "Thucydides Trap" (pp. 52-71). Ann Arbor: University of Michigan Press.

Chan, S. (2020b). Thucydides's Trap? Historical interpretation, logic of inquiry, and the future of Sino-American relations. Ann Arbor: University of Michigan Press.

Chan, S., Feng, H., He, K., \& Hu, W. (2021). Contesting revisionism: China, the United States, and the transformation of international order. Oxford: Oxford University Press. 
Chan, S., Hu, W.X., \& He, K. (2019). Discerning states' revisionist and status-quo orientations: Comparing China and the U.S. European Journal of International Relations, 27(2), 613-640. https://dx.doi.org/10.1177/ 1354066118804622

Copeland, D.C. (2000). The origins of major war. Ithaca, NY: Cornell University Press.

DiCicco, J.M., \& Levy, J.S. (1999). Power shifts and problem shifts: The evolution of the power transition research program. Journal of Conflict Resolution, 43(6), 675-704. https://dx.doi.org/10.1177/0022002799043006001

Farrell, H., \& Newman, A.L. (2019). Weaponized interdependence: How global economic networks shape state coercion. International Security, 44(1), 42-79. https://dx.doi.org/10.1162/isec_a_00351

Gilli, A., \& Gilli, M. (2019). Why China has not caught up yet: Military-technological superiority and the limits of imitation, reverse engineering, and cyber espionage. International Security, 43(3), 141-189. https://dx.doi.org/10.1162/isec_a_00337

Gilpin, R. (1981). War and change in world politics. Cambridge: Cambridge University Press.

Gramsci, A. (1971). Selections from the Prison notebooks of Antonio Gramsci. New York: International Publishers.

Ikenberry, G.J. (2001). After victory: Institutions, strategic restraint, and the rebuilding of order after major wars. Princeton, NJ: Princeton University Press.

Ikenberry, G.J. (2008). The rise of China and the future of the West: Can the liberal system survive? Foreign Affairs, 87(1), 23-37.

Ikenberry, G.J. (2011). The future of the liberal world order: Internationalism after America. Foreign Affairs, 90(3), $56-68$.

Kagan, D. (1969). The outbreak of the Peloponnesian War. Ithaca, NY: Cornell University Press.

Kennedy, P.M. (1987). The rise and fall of great powers. New York: Vintage Books.

Khong, Y.F. (1992). Analogies at war: Korea, Munich, Dien Bien Phu, and the Vietnam decisions of 1965. Princeton, NJ: Princeton University Press.

Kirshner, J. (2019). Handle him with care: The importance of getting Thucydides right. Security Studies, 28(1), 1-24. https://dx.doi.org/10.1080/09636412.2018.1508634

Kugler, J., \& Tammen, R.L. (Eds.). (2012). The performance of nations. Lanham, MD: Rowman \& Littlefield.

Lebow, R.N., \& Valentino, B. (2009). Lost in transition: A critical analysis of power transition theory. International Relations, 23(3), 389-410. https://dx.doi.org/10.1177/0047117809340481

Lee, J. (2019). Did Thucydides believe in Thucydides' Trap? The history of the Peloponnesian War and its relevance to US - China relations. Journal of Chinese Political Science, 24(1), 67-86. https://dx.doi.org/ 10.1007/s11366-019-09607-0

Levy, J.S., \& Thompson, W.R. (2010). Balancing on land and at sea: Do states ally against the leading global power? International Security, 35(1), 7-43. https://doi.org/10.1162/ISEC_a_00001

Lieber, K.A., \& Press, D.G. (2006). The end of MAD: The nuclear dimension of U.S. primacy. International Security, 30(4), 7-44. https://dx.doi.org/10.1162/isec.2006.30.4.7

Nye, J.S.Jr. (2004). Soft power: The means to success in world politics. New York: Public Affairs.

Organski, A.F.K., \& Kugler, J. (1980). The war ledger. Chicago: University of Chicago Press.

Organski, A.F.K. (1958). World politics. New York: Knopf.

Posen, B.R. (2003). Command of the commons: The military foundation of U.S. hegemony. International Security, 28(1), 5-46. https://dx.doi.org/10.1162/016228803322427965

Putnam, R.D. (1988). Diplomacy and domestic politics: The logic of two-level games. International Organization, 42(3), 427-460. https://dx.doi.org/10.1017/S0020818300027697

Rosecrance, R. (1986). The rise of the trading state: Commerce and conquest in the modern world. New York: Basic Books.

Russett, B.M., \& Oneal, J.R. (2001). Triangulating peace: Democracy, interdependence, and international organizations. New York: Norton.

Schweller, R.L. (2006). Unanswered threats: Political constraints on the balance of power. Princeton, NJ: Princeton University Press.

Shifrinson, J. (2018). Falling giants: How great powers exploit power shifts. Ithaca, NY: Cornell University Press.

Singer, J.D., Bremer, S., \& Stuckey, J. (1972). Capability distribution, uncertainty, and major war, 1820-1965. In B.M. Russett (Eds.), Peace, war, and numbers (pp. 19-28). Beverly Hills, CA: Sage.

Starrs, S. (2013). American economic power hasn't declined - it globalized! Summoning the data and taking globalization seriously. International Studies Quarterly, 57(4), 817-830. https://dx.doi.org/10.1111/ isqu. 12053 
Tammen, R.L., Kugler, J., \& Lemke, D. (2017). Foundations of power transition theory. In W.R. Thompson (Eds.), The Oxford encyclopedia of empirical international relations. New York: Oxford University Press. https://dx.doi.org/10.1093/acrefore/9780190228637.013.296

Tammen, R.L., Kugler, J., Lemke, D., Stam, A.III, Abdollahian, M. et al. (2000). Power transitions: Strategies for the 21st century. New York: Chatham House.

Thompson, W.R. (2003). A streetcar named Sarajevo: Catalysts, multiple causation chains, and rivalry structures. International Studies Quarterly, 47(3), 453-474. https://dx.doi.org/10.1111/1468-2478.4703008

Treisman, D. (2004). Rational appeasement. International Organization, 58(2), 345-373. https://dx.doi.org/ $10.1017 / \mathrm{S} 002081830458205 \mathrm{X}$

Vasquez, J.A. (1996). When are power transitions dangerous? An appraisal and reformulation of power transition theory. In J. Kugler \& D. Lemke (Eds.), Parity and war: Evaluations and extensions of the war ledger (pp. 35-56). Ann Arbor: University of Michigan Press.

Waltz, K.N. (1954). Man, the state, and war: A theoretical analysis. New York: Columbia University Press.

Welch, D. (2015). Can the United States and China avoid a Thucydides Trap? E-International Relations, April 6. Retrieved from https://www.e-ir.info/2015/04/06/can-the-united-states-and-china-avoid-a-thucydides-trap/

Wendt, A. (1992). Anarchy is what states make of it: The social construction of power politics. International Organization, 46(2), 391—425. https://dx.doi.org/10.1017/S0020818300027764

\begin{abstract}
About the author: Chan Steve - PhD in Political Science, College Professor of Distinction, Political Science Department, University of Colorado (Boulder), Colorado, USA; ORCID: 0000-0001-9536-8315; e-mail: steve.chan@colorado.edu
\end{abstract}

Сведения об авторе: Чан Стив - кандидат политических наук, почетный профессор департамента политических наук, Университет штата Колорадо, Боулдер, Колорадо, CША; ORCID: 0000-0001-9536-8315; e-mail: steve.chan@colorado.edu 